legal and biological framework for biological diversity research in 2015, coordinated by the Biological Diversity Unit in collaboration with other institutions, and an introductory course on taxonomy, ecology and biogeography of amphibians was offered in 2015. Modest fellowships were offered to those willing to go further and obtain certification for IUCN Red List assessments (http://www.iucnredlist.org/ technical-documents/red-list-training/online-training).

With the support of IVIC, Universidad Centroccidental Lisandro Alvarado, Universidad Nacional Experimental de los Llanos Occidentales Ezequiel Zamora, City University of New York, Fundación La Salle de Ciencias Naturales, Universidad Central de Venezuela, Ministerio del Poder Popular para Ecosocialismo y Aguas, Instituto Socialista de la Pesca y Acuicultura (Insopesca), Provita and the IUCN Species Survival Commission Freshwater Fish Specialist Group, the Biological Diversity Unit offered a course on biogeography, ecology, integrity and conservation of freshwater fishes during 27 April-5 May 2016. Twenty-seven students and professionals combined lectures at IVIC with field trips to a montane watershed on the coast of Aragua, and to the Orinoco river floodplain at Hato Santa Luisa, in Apure, where the owners were generous with their support to the course.

These courses have provided training to more than 200 students, professionals, technicians and governmental agency officials involved in the management of biological diversity. The skills and techniques taught are not part of the traditional curricula of Venezuelan universities, although they are essential for maintaining and strengthening national capacities for management of natural heritage.

Improvement of scientific knowledge is, however, only the initial step in informing conservation policies. Data must be synthesized, and socialized with the public. In January 2016 the Biological Diversity Unit offered a course on writing popular scientific articles in conservation biology, exposing participants to the experience of science journalists, linguists and scientists, and to appropriate media outlets. For 3 weeks, 1 day of lectures per week was combined with writing assignments, leading to short pieces on a topic of choice by each of the 41 participants. The course organizers contacted media outlets to place the articles, and a number have been published or accepted for publication (e.g. http://bit.ly/2agZXwS, http://bit.ly/2aaon64, http://bit. ly/2avQt2L).

During the second semester of 2016 we will continue with courses on georeferencing, species distribution modelling and the legal and biological framework for biological diversity research. We are also exploring the expansion of the courses on natural history and field techniques, and further training in Red List assessments.

Ultimately, our training programme supports conservation policies by helping establish a new cohort of conservation professionals and feeding information into the
Venezuelan Information System on Biological Diversity (http://diversidadbiologica.minamb.gob.ve/), WikiEVA (Threatened Venezuelan Species, http://wikieva.org.ve/), the recent update of the Red List of Venezuelan Fauna (http://animalesamenazados.provita.org.ve/) and the IUCN Red List of Threatened Species (http://www.iucnredlist.org/). Securing financial support to replicate and scale-up this programme at the regional level is the next step.

Haidy Rojas, Dinora Sánchez, Daniel Lew, José $R$. Ferrer-Paris, Jon Paul Rodríguez ${ }^{*}$ J. Celsa Señaris and Grisel Velásquez Centro do Ecología, Instituto Venezolano de Investigaciones Científicas, Venezuela

E-mail hrojas@ivic.gob.ve,dsanchez@ivic.gob.ve

Douglas Rodríguez-Olarte Museo de Ciencias Naturales, Universidad Centroccidental Lisandro Alvarado, Venezuela

Carliz Díaz Dirección General de Diversidad Biológica, Ministerio del Poder Popular para Ecosocialismo y Aguas, Venezuela

${ }^{*}$ Also at: Provita, Venezuela, and IUCN Species Survival Commission, Switzerland

\section{John Muir's little-known 1911 trip to Chile: conserving the historical and ecological legacy}

John Muir, the renowned nature writer, scientist and conservationist, travelled alone to Chile in 1911, at the age of 73, because he wanted to see native forests of Araucaria araucana, the monkey puzzle tree. Few know about this trip because Muir never published anything about it before his death in 1914. In 2012 and 2013 two of us (B. Byers and J. Byers) used Muir's sparse journal notes and sketches to reconstruct his route to the site, now on private land adjacent to Tolhuaca National Park in central Chile, where he finally found Araucaria.

In April 2016 we held a workshop in Chile to outline the first steps for securing the recognition and protection this historically and ecologically important site deserves. The workshop brought together a diverse group of more than 20 people, including representatives from the Corporación Nacional Forestal, which manages Chile's protected areas and forestry sector; the private commercial forestry company that manages the land on which the site is located; academic ecologists and historians; and leaders of Chilean conservation organizations.

The first day of the workshop consisted of presentations and discussions that ranged from forest ecology and history to conservation policy and nature tourism in Chile. Chile's Araucaria forests, although under strict legal protection, face unique threats from land-use and climate change, and invasive species, and are underrepresented in the national 
system of protected areas. Araucaria forests exist in a dynamic relationship with fire, climate and human land uses such as grazing. Private protected areas in Chile offer a lot of flexibility in terms of what they are called, and how and for what purposes they are managed. One category is an 'area of high conservation value', and forest certification organizations recognize and reward forest owners who protect such areas. Around $70 \%$ of the property on which the site visited by Muir is located is native forest, and $30 \%$ is plantations of non-native species, mainly Eucalyptus. A group of nature and ecotourism operators in Malalcahuello, Chile, is interested in the Muir site being opened for limited access so that it can be added to one of the existing national Rutas Patrimoniales (Heritage Routes) in the Araucanía Region, and the National Tourism Service of Chile, SERNATUR, supports this idea.

The second day of the workshop involved a visit to the site where Muir camped and sketched. His sketches provide a unique record of an Araucaria forest at an identifiable site a century ago, and thus a baseline for understanding a century of forest change in the region. The Araucaria forest Muir sketched consisted of large old trees with an open understorey, probably the result of a stand-replacing fire at least several decades before his visit. We found old fire scars on several of the biggest Araucaria at the site, including one of the trees Muir sketched. After 1911 it seems likely that there was little or no fire in this area, indicated by the multi-aged stand of younger Araucaria now growing there, but grazing must have been intense to suppress the regeneration of Nothofagus species, the seedlings of which are eaten by cattle.

Following the workshop we are continuing to discuss options for a formal conservation agreement for the site with the private forestry company and other stakeholders. We are planning further studies to understand the fire history and forest dynamics that led to the current forest condition at the site, and we are also working on a plan for limited and regulated access so that local ecotourism operators can start marketing trips to the site to groups of specialized clients.

BRUCE A. BYERS Bruce Byers Consulting, Falls Church, Virginia, USA. E-mail bruce.byers@verizon.net

Jonathan Byers Alpine of the Americas Project, El Portal, California, USA

Mauro E. Gonzalez Facultdad de Ciencias Forestales y Recursos Naturales, Universidad Austral de Chile, Valdivia, Chile

Aníbal Pauchard Universidad de Concepción-Facultad de Ciencias Forestales, Concepción, Chile

Sergio Pérez Suizandina Lodge, Malalcahuello, Chile

\section{A 90-year-old mystery solved: a potentially new species of owl from Príncipe}

In a recent expedition to a remote rainforest on the island of Príncipe, in the Gulf of Guinea, an apparently undescribed species of scops owl was observed. The owl appears to have vocalizations unlike any known scops owl. The news was first announced at an international conference on island biology in the Azores in July 2016.

Early explorers to Príncipe reported in 1928 that inhabitants of the island indicated the presence of a small and rare owl species; however, despite several expeditions, researchers failed to find it. In 1998 one of us (M. Melo) collected testimonials of local parrot trappers, who described seeing a scops-owl like bird in tree holes in the rainforest, and later reported that in the most remote forests one could hear unknown calls within the frequency range of scops owl calls (Melo \& Dallimer, 2009, Malimbus, 31, 109-115).

In July 2016 P. Verbelen \& F. Spina organized an expedition to Príncipe in search of the presumed owl. During 5 days in the southern rainforests the unidentified calls, from high in the forest canopy, were heard at various locations. The owl was lured into view, and was photographed and recorded at close range when an individual descended from the canopy in response to playback of its own recorded calls. A formal description of the Príncipe scops owl is now in preparation.

The islands of São Tomé and Príncipe harbour 28 endemic bird species (29 including the new owl species) and have thus been dubbed the African Galapagos and the lost Eden of Africa. The rainforests on the islands are a global priority for biodiversity conservation, especially for birds, and the Natural Park of São Tomé and Príncipe is considered an irreplaceable protected area. In 2016 Fauna \& Flora International joined forces with the Príncipe Trust Foundation to enhance the conservation of the island's outstanding biodiversity. A collaboration agreement was signed, a conservation strategy defined and two conservation managers seconded to the Foundation.

PhILIPPe Verbelen Ghent, Belgium

Martim Melo Research Centre in Biodiversity and Genetic Resources, Porto University, Lisbon, Portugal

GEORGE SANGSTER Department of Bioinformatics and Genetics, Swedish Museum of Natural History, Stockholm, Sweden

FELIPE SPINA Príncipe Trust Foundation and Fauna \& Flora International, São Tomé and Príncipe

E-mail felipe.spina@fauna-flora.org 